\title{
R-factor Mediated Resistance to Penicillins which does not Involve a $\beta$-Lactamase
}

\author{
By N. A. C. CURTIS, M. H. RICHMOND AND V. STANISICH* \\ Department of Bacteriology, University of Bristol, University Walk, Bristol BS8 ITH
}

(Received I5 May 1973)

The R-factor RP I was originally detected in Pseudomonas aeruginosa strain I822 (Lowbury, Kidson, Lilly, Ayliffe \& Jones, I969; Sykes \& Richmond, I970; Fullbrook, Elson $\&$ Slocombe, 1970), where it confers resistance to tetracycline, neomycin, kanamycin and a wide range of $\beta$-lactam antibiotics including carbenicillin (Grinsted, Saunders, Ingram, Sykes \& Richmond, I972). This plasmid is a member of the P-class of R-factors and specifies its own transfer between $P$. aeruginosa and a number of species of enteric bacteria (Datta, Hedges, Shaw, Sykes \& Richmond, 1972). When in enteric species, it expresses the same marker pattern as found in $P$. aeruginosa (Table $\mathrm{I}$ ).

Much of the interest in this plasmid has centred on its protection of clinical strains of Pseudomonas aeruginosa against carbenicillin therapy (Lowbury et al. 1969; Ingram, Richmond \& Sykes, I973), a property ascribed to the production of the type III a $\beta$-lactamase (Richmond \& Sykes, 1973) specified by the R-factor. However, it has always seemed slightly surprising that an enzyme that hydrolyses carbenicillin relatively poorly (Sykes \& Richmond, I97I) should nevertheless produce at least a 1000-fold increase in resistance to the bacteria expressing it (Table I). The isolation of a mutant of RP I which no longer codes for $\beta$-lactamase synthesis but which nevertheless still confers penicillin resistance to the bacteria that carry it, argues that RP I specifies intrinsic resistance to penicillins as well as $\beta$-lactamase production and that these two characters co-operate to produce the carbenicillin resistant phenotypes found in $P$. aeruginosa.

Pseudomonas aeruginosa I 822 (RP I) was grown exponentially in nutrient broth and the bacteria collected by centrifuging when the culture density had reached about $10^{9}$ organisms/ $\mathrm{ml}$. The organisms were resuspended in $0^{\circ} \mathrm{I} \mathrm{M}$ citrate buffer, $\mathrm{pH} 5.0$, containing $100 \mu \mathrm{g}$ $N$-methyl- $N$-nitro- $N^{\prime}$-nitrosoguanidine $/ \mathrm{ml}$ and maintained at $37{ }^{\circ} \mathrm{C}$ without shaking. After I 5 min the culture was centrifuged and the bacteria resuspended in fresh nutrient broth to a density of about $10^{9}$ organisms $/ \mathrm{ml}$. This culture was immediately mated with $P$. aeruginosa PS I 8s adestr-r using equal volumes of donor and recipient bacteria each at a density of about $10^{9}$ bacteria $/ \mathrm{ml}$. The mating was continued for $15 \mathrm{~min}$ at $37^{\circ} \mathrm{C}$ and the mixture was then treated briefly with a vortex mixer to separate mating pairs. Samples were plated at appropriate dilutions on agar containing $250 \mu \mathrm{g}$ streptomycin and $200 \mu \mathrm{g}$ tetracycline $/ \mathrm{ml}$. Colonies obtained after overnight growth were spotted with tooth-picks on to nutrient agar containing one of the following antibiotics: carbenicillin $(250 \mu \mathrm{g} / \mathrm{ml})$, streptomycin $(250$ $\mu \mathrm{g} / \mathrm{ml})$ or tetracycline $(200 \mu \mathrm{g} / \mathrm{ml})$. One isolate resistant to tetracycline and streptomycin but relatively sensitive to carbenicillin was obtained from the 1200 colonies tested.

The isolated mutant colony was compared with the parental strain, and with its plasmidless variant, for production of $\beta$-lactamase both iodometrically (Novick, I962) and spectrophotometrically with the chromogenic cephalosporin substrate (O'Callaghan, Morris,

* Present address: Department of Genetics, Monash University, Clayton, Australia. 
Table I. Effect of $R P P_{\mathrm{I}}$ and of the mutated $R P$ I plasmid on the resistance of $P_{\text {seudomonas }}$ aeruginosa and Escherichia coli to a range of antibiotics

\begin{tabular}{|c|c|c|c|c|c|c|c|c|c|}
\hline & & & & & MIC & $\mathrm{g} / \mathrm{ml})$ & & & \\
\hline Strain & Plasmid & $\mathrm{Neo}$ & Kana & Tet & PenG & Amp & Carb & CER & 6APA \\
\hline Pseudomonas & - & 8 & $(\mathrm{NT})$ & 16 & 625 & 160 & 80 & I 250 & I 250 \\
\hline aeruginosa i 822 & RP I & 1000 & $(\mathrm{NT})$ & 500 & 5000 & 5000 & 5000 & 5000 & 2500 \\
\hline & RPI mutant & I 000 & $(\mathrm{NT})$ & 500 & I 250 & 625 & I 60 & 2500 & 2500 \\
\hline & - (cured) & 4 & $(\mathrm{NT})$ & 8 & 625 & 160 & 40 & I 250 & I 250 \\
\hline Escherichia coli & - & 2 & 4 & 2 & 20 & 4 & 4 & 2 & $8 c$ \\
\hline w3110 & RP I & 63 & 250 & 125 & 10000 & 10000 & 10000 & 8 & 2500 \\
\hline & RP I mutant & 63 & 250 & 125 & 625 & 625 & 2500 & 8 & 625 \\
\hline & - cured & 4 & 2 & 2 & 20 & 5 & 5 & 5 & 80 \\
\hline
\end{tabular}

Neo, neomycin; Kana, kanamycin; Tet, tetracycline; PenG, benzyl penicillin; Amp, ampicillin; Carb, carbenicillin; CER, cephaloridine; 6APA, 6-amino-penicillanic acid; (NT), not tested.

Kirby \& Shingler, I972). While the parent synthesized about I20 enzyme units/mg dry wt bacteria with benzyl penicillin as substrate, the mutant and the $\mathrm{R}^{-}$variant produced less than $0 \cdot$ I unit/mg dry wt Furthermore, tests with specific anti-type III a serum (Datta \& Richmond, 1966) showed no enzyme production either by the mutant or the $\mathrm{R}^{-}$variant while the parent expressed relatively large amounts of type III a enzyme.

Pseudomonas aeruginosa strain PsI8s carrying the mutant plasmid was mated with Escherichia coli $\mathrm{KI} 2$ ( $r i f-\mathrm{r}$ ) and the cross selected on plates containing $\mathrm{I} 00 \mu \mathrm{g}$ tetracycline and I $00 \mu \mathrm{g}$ rifampicin $/ \mathrm{ml}$. Colonies of $E$. coli carrying the mutated plasmid obtained in this way were then tested for the type and amount of $\beta$-lactamase synthesis, $E$. coli RP I and $E$. coli $\mathrm{R}^{-}$ being included for comparison. As with the equivalent $P$. aeruginosa strains, $E$. coli KI $2 \mathrm{R}^{-}$ and $E$. coli KI 2 carrying the mutated version of RP I synthesized less than $0 \cdot 1$ enzyme unit/mg dry wt bacteria when measured with benzyl penicillin as substrate, while $E$. coli KI2 RP I expressed about 450 units/mg dry wt bacteria.

Attempts to revert the strains carrying the mutant plasmid (whether carried in Escherichia coli or Pseudomonas aeruginosa) by further nitrosoguanidine treatment failed, nor have any $\beta$-lactamase producing revertants ever arisen from this mutant version of RP I. The original mutagenesis has therefore probably deleted the $\beta$-lactamase gene but left the genes specifying resistance to neomycin, kanamycin and tetracycline intact.

Examination of the resistance pattern of these strains shows that in both Pseudomonas aeruginosa and Escherichia coli the loss of the plasmid-mediated $\beta$-lactamase gene did not significantly alter the mean inhibitory concentration (MIC) values obtained with neomycin, kanamycin and tetracycline. MIC values against a range of penicillins, however, were decreased, but not to the levels characteristic of R-cultures. Strains of $E$. coli carrying the mutant plasmid were still at least 30 -fold more resistant than the plasmid-less controls, although this difference was not so great in P. aeruginosa (Table I). The plasmid RP I confers little resistance to cephaloridine and the MIC values obtained against this antibiotic were unchanged when the mutant plasmid was present. It follows that the $\beta$-lactamase produced by strains carrying RP I cannot be the only factor influencing their penicillin resistance. Furthermore, no destruction of either benzylpenicillin or cephaloridine could be detected even after prolonged incubation with broken cell preparations (Jack \& Richmond, 1970) of either $P$. aeruginosa or $E$. coli carrying the mutated R-factor. The partial resistance of these strains could not therefore be due to a penicillin or cephalosporin amidase.

To confirm that the relatively high level of residual resistance to penicillins was due to an 
R-factor mediated character and not to some cell-linked gene, both the Escherichia coli and the Pseudomonas aeruginosa strains carrying the mutant plasmid were treated with sodium dodecyl sulphate by the method of Tomoeda, Inuzuka, Kubo \& Nakamura (I968) and tetracycline-sensitive variants isolated. All these variants were also sensitive to neomycin and kanamycin, and moreover their resistance to penicillins had fallen to values characteristic of the $\mathrm{R}^{-}$variant of the strains in question (Table I). Reinsertion of RP I or mutant RP I into $\mathrm{R}$ - recipients re-established the resistant phenotypes at the expected levels.

Plasmid-free strains of Pseudomonas aeruginosa and Escherichia coli $\mathrm{KI} 2$ produce very small amounts of $\beta$-lactamase when free of R-factors (Lindström, Boman \& Steele, 1970; Sykes \& Richmond, 197I), the enzymes being of types Id and Ia respectively (Richmond \& Sykes, 1973). The high penicillin resistance of the strains carrying the mutated R-factor might therefore be due to an alteration in the amount of these enzymes expressed by the strains. All type I enzymes are predominantly active against cephalosporins and inactive against carbenicillin, which inhibits them (Richmond \& Sykes, 1973). Examination of the residual enzyme activity in both the $E$. coli and the $P$. aeruginosa strains carrying the mutant $\mathrm{R}$-factor showed that the low level of $\beta$-lactamase present (always less than $0.1 \mathrm{unit} / \mathrm{mg}$ dry wt bacteria) was predominantly active against cephalosporins and inhibited by carbenicillin, and therefore could not itself be contributing to the carbenicillin resistance of the strains lacking type III a enzyme.

Although these preliminary studies show that RP I seems to carry a locus that specifies penicillin resistance by a mechanism other than enzyme destruction, the biochemical basis of the resistance is unknown. R-factors certainly can modify the permeability properties of membranes (Franklin, 1967) and perhaps this process is involved here. Nor is it yet clear how widespread this R-factor mediated intrinsic resistance may be. The answer to that point must await the isolation of appropriate mutants from a range of other $R$-factors.

This work was supported by grants from the M.R.C. to M.H.R. and jointly from the S.R.C. and Glaxo Research Ltd to N.A.C.C.

\section{REFERENCES}

Datta, N., Hedges, R. W., Shaw, E. J., Sykes, R. B. \& Richmond, M. H. (1972). Properties of an R-factor isolated from Pseudomonas aeruginosa. Journal of Bacteriology 108, I 244-1249.

DatTa, N. \& Richmond, M. H. (I966). The purification and properties of a penicillinase whose synthesis is mediated by an $R$-factor in Escherichia coli. Biochemical Journal 98, 204.

Franklin, T. J. (1967). Resistance of Escherichia coli to tetracyclines: changes in permeability to tetracyclines in E. coli bearing transferable resistance factors. Biochemical Journal 105, 371-378.

Fullbrook, P. D., Elson, S. W. \& Slocombe, B. (1970). R-factor mediated $\beta$-lactamase in Pseudomonas aeruginosa. Nature, London 226, 1054-1056.

Grinsted, J., Saunders, J. R., Ingram, L. C., Sykes, R. B. \& Richmond, M. H. (1972). Properties of an R-factor which originated in Pseudomonas aeruginosa 1822. Journal of Bacteriology 110, 529-537.

IngRAM, L., Richmond, M. H. \& SyKes, R. B. (1973). The characteristics of the plasmids in a series of strains isolated from burned patients. Antimicrobial Agents \& Chemotherapy 3, 279-288.

JACK, G. W. \& RiChmOND, M. H. (1970). A comparative study of eight distinct $\beta$-lactamases synthesised by Gram-negative bacteria. Journal of General Microbiology 6r, 43-6r .

Lindström, E. B., Boman, H. G. \& SteEle, B. (1970). Resistance of Escherichia coli to penicillins. VI. Purification and characterisation of the chromosomally mediated penicillinase present in ampA-containing strains. Journal of Bacteriology Ior, 21 8-23I.

Lowbury, E. J. L., Kidson, A., Lilly, H. A., Ayliffe, G. A. J. \& Jones, R. J. (1969). Sensitivity of Pseudomonas aeruginosa to antibiotics: emergence of strains highly resistant to carbenicillin. Lancet ii, $448-452$.

Novick, R. P. (1962). Staphylococcal penicillinase and the new penicillins. Biochemical Journal 83, 229-235. 
O'Callaghan, C., Morris, A., Kirby, S. M. \& Shingler, A. H. (I972). Novel method for detection of $\beta$-lactamase by using a chromogenic cephalosporin substrate. Antimicrobial Agents and Chemotherapy $\mathbf{r}$, 283-288.

Richmond, M. H. \& SyKes, R. B. (I973). The $\beta$-lactamases of Gram-negative bacteria and their possible physiological role. In Advances in Microbial Physiology, vol. 9, pp. 3I-85. Edited by A. H. Rose and D. W. Tempest. London and New York: Academic Press.

SyKes, R. B. \& Richmond, M. H. (1970). The intergeneric transfer of a $\beta$-lactamase gene between Escherichia coli and Pseudomonas aeruginosa. Nature, London 226, 952-954.

Sykes, R. B. \& Richmond, M. H. (I97I). R-factors, $\beta$-lactamase, and carbenicillin-resistant Pseudomonas aeruginosa. Lancet ii, 342-344.

Tomoeda, M., Inuzuka, M., Kubo, N. \& Nakamura, S. (I968). Effective elimination of drug resistance and sex factors in Escherichia coli by sodium dodecyl sulphate. Journal of Bacteriology 95, 1078-1089. 